\title{
Pengaruh Penggunaan Tempe Dedak dan Tape Dedak terhadap Kualitas Karkas Ayam Broiler
}

\author{
Agung Rahmat ${ }^{1}$, Yosi Fenita ${ }^{1}$ dan Urip Santoso ${ }^{1 *}$ \\ ${ }^{1} J u r u s a n$ Peternakan, Fakultas Pertanian, Universitas Bengkulu JI. WR. Supratman Kel. Kandang Limun \\ Kec. Muara Bangkahulu Bengkulu 38371A \\ *Penulis korespondensi : santoso@unib.ac.id
}

Artikel ini diterima (received): 16 Maret 2021; dinyatakan disetujui (accepted): 29 Mei 2021; terbit (published): 30 Mei 2021. Artikel ini dipublikasi secara daring pada https://ejournal.unib.ac.id/index.php/buletin_pt/index

\begin{abstract}
Abstrak
Penelitian ini bertujuan untuk mengevaluasi pengaruh tempe dedak dan tape dedak terhadap kualitas karkas ayam broiler. Seratus dua puluh ekor ayam broiler jantan didistribusikan ke dalam 5 kelompok perlakuan dengan 4 ulangan sebagai berikut: $\mathrm{P} 1=$ ransum mengandung tempe dedak $14 \%$; $\mathrm{P} 2=$ ransum mengandung tempe dedak $20 \%$; $\mathrm{P} 3=$ ransum mengandung tape dedak $14 \%$ dan; $\mathrm{P} 4=$ ransum mengandung tape dedak $20 \%$. Hasil penelitian menunjukkan bahwa tempe dedak dan tape dedak berpengaruh tidak nyata $(P>0,05)$ terhadap berat karkas, meat bone ratio, cooking loss dan drip loss. Perlakuan menghasilkan warna karkas yang relatif sama. Dapat disimpulkan bahwa pemberian tempe dedak dan tape dedak dapat diberikan kepada ayam broiler sebanyak $20 \%$ tanpa menurunkan kualitas karkas
\end{abstract}

Kata kunci: tempe dedak, tape dedak, kualitas karkas, broiler.

\section{Pendahuluan}

Pakan merupakan masalah paling utama pada usaha peternakan ayam broiler, dikarenakan biaya pakan sangat tinggi, yaitu berkisar antara $50-80 \%$ dari total biaya produksi. Selain itu, untuk mencapai pertumbuhan dan produksi yang maksimal maka kualitas dan kuantitas pakan harus memadai. Pakan yang murah tetapi berkualitas tinggi akan menghasilkan produksi yang efisien. Untuk itu, pemilihan bahan pakan yang berkualitas baik dan murah harganya menjadi sangat penting.

Salah satu bahan pakan yang banyak tersedia dan harganya murah adalah dedak padi. Dedak padi mengandung protein $11,3 \%$, lemak $15 \%$, dan serat kasar $7 \%$, dan merupakan sumber vitamin B dan E (Champagne et al., 1992). Dedak padi mengandung komponen bioaktif seperti fitosterol, tokoferol, tokotrienol, dan oryzanol dapat menurunkan kadar kolesterol dan sebagai sumber antioksidan
(Saunders, 1985). Namun, dedak padi mempunyai beberapa kelemahan, yaitu serat kasar dan asam fitat yang tinggi. Asam fitat mampu mengikat mineral $\mathrm{Ca}$ dan $\mathrm{P}, \mathrm{Fe}$, dan $\mathrm{Zn}$ dan mengikat protein menjadi fitat-protein kompleks, sehingga menurunkan penggunaan zat gizi tersebut bagi unggas.

Penggunaan dedak padi dalam pakan broiler hanya dapat diberikan maksimal 5\% (Santoso et al., 2015). Selanjutnya dinyatakan bahwa untuk meningkatkan penggunaan dedak padi, maka bahan pakan ini dapat difermentasi. Menurut Bidura (2007), keuntungan fermentasi oleh mikroba adalah mampu mengubah makro molekul protein menjadi mikro molekul yang mudah dicerna oleh unggas serta tidak menghasilkan senyawa kimia beracun. Dilaporkan juga, selain dapat meningkatkan kandungan protein dalam ransum, fermentasi juga dapat meningkatkan kecernaan pakan dan dapat melepas ikatan senyawa kompleks menjadi senyawa yang mudah dicerna. 
Fermentasi meningkatkan kecernaan zat gizi pada unggas, sehingga meningkatkan pertumbuhan dan efisiensi penggunaan pakan (Kiers et al., 2003).

Bidura et al. (2012) menyatakan bahwa dedak yang difermentasi dengan Saccharomyces sp yang diisolasi dari ragi tape pada level 0,20-0,40\% dapat meningkatkan kadar protein dedak. Penggunaan ragi tape sebagai inokulan fermentasi meningkatkan kandungan protein pakan dan sebaliknya nyata menurunkan kandungan serat kasar pakan (Widiyazid et al., 2002). Dilaporkan juga bahwa fermentasi dengan kapang Rhizopus oligosporus dapat menyederhanakan partikel bahan pakan, sehingga akan meningkatkan nilai gizinya, serta mengubah protein kompleks menjadi asam amino sederhana yang mudah diserap (Mahfudz et al., 1996). Dedak yang difermentasi dengan ragi tempe dapat meningkatkan kualitas protein, meningkatkan ketersediaan mineral, dan menurunkan anti nutrisi. Berdasarkan hasil penelitian Widyastuti (2017) bahwa pemberian tempe dedak dapat diberikan sebanyak $14 \%$ dengan menghasilkan kualitas karkas yang cenderung lebih tinggi, oleh sebab itu pemberian tempe dedak dapat ditingkatkan. Dedak yang difermentasi dengan ragi tempe dilanjutnya disebut tempe dedak dan dedak yang difermentasi dengan ragi tape disebut tape dedak (Fitriyani et al., 2019; Fatimah et al., 2020; Kurniati et al., 2020). Selanjutnya dinyatakan bahwa tempe dedak dan tape dedak mempunyai kualitas gizi yang lebih tinggi daripada dedak, sehingga diduga penggunaannya dapat diberikan di atas 5\% tanpa menurunkan kualitas karkas broiler.

Penelitian ini bertujuan untuk mengevaluasi pengaruh pemberian tempe dedak dan tape dedak terhadap kualitas karkas ayam broiler. Tempe dedak dan tape dedak diduga dapat diberikan sampai $20 \%$ tanpa menurunkan kualitas karkas ayam broiler.

\section{Bahan dan Metode}

Pembuatan Tempe Dedak dan Tape Dedak

Pembuatan tempe dedak dilakukan dengan cara dedak dicampur dengan air dengan perbandingan 1:1, kemudian dedak dikukus selama 30 menit. Tujuan pengukusan adalah untuk membuat dedak menjadi lebih lunak dan juga untuk mengurangi kontaminan. Setelah 30 menit dedak diambil dan didinginkan. Setelah dingin dedak ditaburi ragi tempe (Rhizopus oligosparus) sebanyak 4 gram per $\mathrm{kg}$ dedak. Lalu dimasukkan kedalam plastik dan plastik ditutup rapat. Plastik kemudian dilubangi untuk memudahkan pertukaran udara, sebab ragi tempe memerlukan oksigen untuk pertumbuhannya. Fermentasi dedak selama 78 jam. Dedak hasil fermentasi dijemur sampai kering dan selanjutnya digiling agar menjadi halus. Tempe dedak disimpan dalam plastik untuk selanjutnya dicampur dalam ransum sesuai perlakuan dan diberikan pada unggas.

Cara pembuatan tape dedak tidak jauh berbeda dari pembuatan tempe dedak. Pertama-tama dedak dicampur dengan air dengan perbandingan 1:1, dedak kemudian dikukus selama 30 menit. Tujuan pengukusan adalah selain untuk membuat dedak lebih lunak, juga untuk mengurangi kontaminan. Setelah 30 menit, dedak diambil dan didinginkan, setelah dingin, dedak ditaburi ragi tape (Saccharomyces cereviseae) sebanyak 5 gram per kg dedak. Lalu dimasukkan ke dalam plastik, plastik ditutup rapat. Plastik tidak dilubangi sebab ragi tape tidak memerlukan oksigen untuk pertumbuhannya. Fermentasi dedak selama 48 jam. Dedak hasil fermentasi dijemur sampai kering dan selanjutnya digiling agar menjadi halus. Tape dedak disimpan dalam plastik untuk dicampur dalam ransum sesuai perlakuan dan diberikan pada unggas.

\section{Pemeliharaan Ayam Broiler}

Sebanyak 300 ekor day old chick (DOC) ayam broiler ditempatkan dalam kandang brooding. Ayam broiler yang baru datang diberi air gula untuk mengurangi stres akibat perjalanan. Pada umur 4 dan 21 hari, ayam broiler divaksin Newcastle Disease (ND). Selama umur 1-21 hari ayam broiler diberi ransum komersial. Pada umur 21 hari, sebanyak 120 ekor ayam broiler jantan diseleksi dari 300 ekor selanjutnya didistribusikan ke dalam petak-petak percobaan dan diberi ransum percobaan sampai dengan umur 42 hari.

\section{Rancangan penelitian}

Penelitian ini menggunakan Rancangan Acak Lengkap (RAL) dengan 5 perlakuan dan 4 ulangan. Pada masing-masing ulangan terdapat 
6 ekor ayam broiler. Perlakuan dibedakan berdasarkan level pemberian tempe dedak dan tape dedak yang berbeda dalam ransum. Susunan pakan penelitian telah dipublikasikan di tempat lain (Fatimah et al., 2020).

Adapun perlakuan yang digunakan adalah sebagai berikut: $\mathrm{PO}=$ ransum mengandung dedak $5 \%$; $\mathrm{P} 1=$ ransum mengandung tempe dedak $14 \% ; \mathrm{P} 2=$ ransum mengandung tempe dedak $20 \%$; $\mathrm{P} 3=$ ransum mengandung tape dedak $14 \%$ dan; $\mathrm{P} 4=$ ransum mengandung tape dedak $20 \%$.

\section{Pengambilan Sampel}

Pada umur 42 hari 6 ekor broiler jantan pada setiap perlakuan dan ditimbang dan diselekasi. Sebelum dilakukan penyembelihan, ayam dipuasakan terlebih dahulu selama 12 jam. Broiler kemudian disembelih dan diukur warna karkas, berat karkas, persentase berat karkas, meat bone ratio, cooking loss dan drip loss.

\section{Analisis Data}

Warna karkas dianalisis secara deskriptif, sedangkan berat karkas, persentase berat karkas, meat bone ratio, cooking loss dan drip loss dianalisis dengan sidik ragam. Jika hasil sidik ragam berpengaruh nyata maka diuji lanjut dengan Duncan's Multiple Range Test untuk melihat perbedaan antar perlakuan.

\section{HASIL DAN PEMBAHASAN}

\section{Warna Karkas}

Pengaruh tempe dedak dan tape dedak terhadap warna karkas disajikan pada Tabel 1. Hasil penelitian menunjukkan bahwa warna karkas untuk P0, P1, P2, P3 dan P4 masingmasing adalah 101,88, 101,88, 101,88, 102,13 dan 101,38. Berdasarkan data tersebut maka P4 mempunyai warna karkas yang lebih rendah daripada perlakukan lainnya. Warna karkas pada P4 yang lebih pucat dipengaruhi oleh zat warna karotenoid yaitu santofil. Santofil terutama berasal dari jagung dalam ransum. Menurut Vandrell et al. (2001) santofil sangat efektif utnuk meningkatkan warna kuning telur dan kulit karkas ayam broiler. Menurut Samudra dan Arief (2008) bahwa pigmen yang diperoleh dari pakan akan terakumulasi di jaringan, selanjutnya akan terabsorbsi dalam darah dan diedarkan keseluruh tubuh yang selanjutnya memberikan efek pigmentasi pada warna kulit karkas.

Sangat menarik, meskipun penggunaan jagung lebih rendah pada P1, P2 dan P3, warna karkas relatif sama dengan PO. Diduga tempe dedak dan tape dedak mempunyai kadar polifenol yang lebih tinggi daripada dedak, sehingga diduga mampu menjaga penurunan warna karkas akibat penurunan pemberian jagung. Selain itu, terdapat dugaan bahwa tempe dedak dan tape dedak yang dicampurkan dengan bahan pakan lain termasuk jagung dapat meningkatkan kecernaan santofil pakan. Namun, pemberian $20 \%$ tape dedak menurunkan warna karkas. Hal ini menunjukkan bahwa P4 mengandung santofil yang lebih rendah. Belum diketahui mekanisme lebih rendahnya warna karkas pada P4

\section{Berat Karkas}

Pengaruh tempe dedak dan tape dedak terhadap berat karkas disajikan pada Tabel 2 . Hasil analisis ragam menunjukkan bahwa pemberian tempe dedak dan tape dedak berpengaruh tidak nyata $(P>0,05)$ terhadap berat karkas .

Tabel 1. Pengaruh pemberian tempe dedak dan tape dedak terhadap warna karkas

\begin{tabular}{|c|c|c|c|c|c|}
\hline \multirow{2}{*}{ Perlakuan } & \multicolumn{4}{|c|}{ Ulangan } & \multirow{2}{*}{ Rata- Rata $\pm S D$} \\
\hline & U1 & U2 & U3 & U4 & \\
\hline PO & 102,00 & 102,00 & 101,50 & 102,00 & $101,88 \pm 0,25$ \\
\hline P1 & 101,50 & 102,00 & 102,00 & 102,00 & $101,88 \pm 0,25$ \\
\hline P2 & 102,00 & 101,50 & 102,00 & 102,00 & $101,88 \pm 0,25$ \\
\hline P3 & 102,50 & 102,00 & 101,50 & 102,50 & $102,13 \pm 0,48$ \\
\hline P4 & 101,50 & 101,50 & 101,00 & 101,50 & $101,38 \pm 0,25$ \\
\hline
\end{tabular}

Keterangan : $\mathrm{P} 0=$ pakan mengandung 5\% dedak, $\mathrm{P} 1=$ pakan mengandung $14 \%$ tempe dedak, $\mathrm{P} 2=$ pakan mengandung $20 \%$ tempe dedak, $\mathrm{P} 3=$ pakan mengandung $14 \%$ tape dedak, $\mathrm{P} 4=$ pakan mengandung $20 \%$ tape dedak; SD= Standar Deviasi 
Tabel 2. Pengaruh pemberian tempe dedak dan tape dedak terhadap berat karkas

\begin{tabular}{|c|c|c|c|c|c|}
\hline \multirow{2}{*}{ Perlakuan } & \multicolumn{4}{|c|}{ Ulangan } & \multirow{2}{*}{ Rata- Rata $\pm S D$} \\
\hline & U1 & U2 & U3 & U4 & \\
\hline \multicolumn{6}{|c|}{ 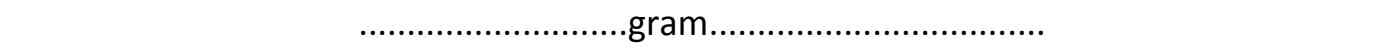 } \\
\hline PO & 1147,02 & 1086,83 & 1124,65 & 1197,77 & $1139,07 \pm 46,35$ \\
\hline P1 & 1242,49 & 1120,19 & 1102.41 & 1225,17 & $1172,57 \pm 71,46$ \\
\hline P2 & 1127,11 & 1216,41 & 1094,59 & 1138,15 & $1144,07 \pm 51,65$ \\
\hline P3 & 1130,08 & 1203.98 & 1210,49 & 1114,48 & $1164,76 \pm 49,53$ \\
\hline P4 & 1131,38 & 1110,47 & 1165,69 & 1196,89 & $1151,11 \pm 38,08$ \\
\hline
\end{tabular}

ns = menunjukkan perlakuan berpengaruh tidak nyata $(\mathrm{P}>0,05) ; \mathrm{P0}=$ pakan mengandung $5 \%$ dedak, $\mathrm{P} 1=$ pakan mengandung $14 \%$ tempe dedak, $\mathrm{P} 2=$ pakan mengandung $20 \%$ tempe dedak, $\mathrm{P} 3=$ pakan mengandung $14 \%$ tape dedak, $\mathrm{P} 4=$ pakan mengandung 20\% tape dedak; SD= Standar Deviasi

Pakan P1, P2, P3 dan P4 mengandung energi yang lebih rendah jika dibandingkan dengan pakan PO. Energi pakan yang lebih rendah akan meningkatkan konsums pakan. Namun, Fatimah et al. (2020) melaporkan bahwa pemberian tempe dedak dan tape dedak cenderung menurunkan konsumsi pakan. Oleh sebab itu, terdapat faktor lainnya yang menyebabkan berat karkas pada pakan yang mengandung tempe dedak atau tape dedak mempunyai berat karkas yang relatif sama dengan kontrol (P0). Fatimah et al. (2020) melaporkan bahwa meningkatkan kadar protein dedak dan menurunkan kadar serat kasar dan asam fitat. Jadi, perbaikkan kualitas dedak oleh fermentasi merupakan salah satu faktor penyebab tidak menurunnya berat karkas pada broiler yang diberi tempe dedak dan tape dedak. Selain itu, Fatimah et al. (2020) melaporkan bahwa pemberian tempe dedak dan tape dedak cenderung meningkatkan efisiensi penggunaan pakan.

\section{Persentase Berat Karkas}

Pengaruh tempe dedak dan tape dedak terhadap berat karkas disajikan pada Tabel 3 . Hasil analisis ragam menunjukkan bahwa pemberian tempe dedak dan tape dedak berpengaruh tidak nyata $(P>0,05)$ terhadap persentase karkas. Hasil persentase karkas penelitian ini masih berada dalam nilai standar persentase karkas menurut Soeparno (2015) yaitu 65\%-75\%. Hal ini menunjukkan penggunaan tempe dedak dan tape dedak hingga 20\% tidak menurunkan persentase karkas. Widyastuti (2017) mendapatkan persentase karkas berkisar antara 67,04\%$68,66 \%$. Berdasarkan data persentase berat karkas, tempe dedak dan tape dedak dapat diberikan sebanyak $20 \%$.

Tabel 3. Pengaruh pemberian tempe dedak dan tape dedak terhadap persentase karkas

\begin{tabular}{|c|c|c|c|c|c|}
\hline \multirow{2}{*}{ Perlakuan } & \multicolumn{4}{|c|}{ Ulangan } & \multirow{2}{*}{ Rata- Rata \pm SD } \\
\hline & U1 & U2 & U3 & U4 & \\
\hline \multicolumn{6}{|c|}{ 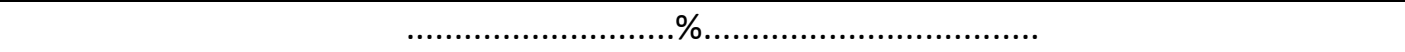 } \\
\hline PO & 69,90 & 65,99 & 67,51 & 70,00 & $68,35 \pm 1,95$ \\
\hline P1 & 69,49 & 69,92 & 69,77 & 70,37 & $69,89 \pm 0,37$ \\
\hline P2 & 68,27 & 75,27 & 67,86 & 67,75 & $69,79 \pm 3,66$ \\
\hline P3 & 68,45 & 69,88 & 71,50 & 67,02 & $69,21 \pm 1,92$ \\
\hline P4 & 70,23 & 67,63 & 69,72 & 70,65 & $69,56 \pm 1,34$ \\
\hline Probabilitas & & & & & $0,848^{\text {ns }}$ \\
\hline
\end{tabular}




\section{Meat Bone Ratio}

Pengaruh tempe dedak dan tape dedak terhadap berat karkas disajikan pada Tabel 4 . Hasil analisis ragam menunjukkan bahwa pemberian tempe dedak dan tape dedak berpengaruh tidak nyata $(P>0,05)$ terhadap meat bone ratio.

Peningkatan kualitas dedak pada tempe dedak dan tape dedak diduga merupakan salah satu faktor tidak menurunnya meat bone ratio. Fermentasi dengan ragi tempe dan ragi tape meningkatkan kadar protein dan menurunkan kadar serat kasar dan asam fitat (Fatimah et al., 2020). Lebih rendahnya asam fitat pada tempe dedak dan tape dedak meningkatkan kecernaan mineral dan protein, sementara penurunan serat kasar diduga menyediakan penambahan energi bagi broiler. Penambahan energi dikarenakan penurunan serat kasar ini diduga merupakan salah satu faktor penyebab tercukupinya kebutuhan energi untuk broiler. Dapat disimpulkan bahwa tempe dedak dan tape dedak dapat diberikan sebanyak $20 \%$ tanpa menurunkan meat bone ratio.

Tabel 4. Pengaruh pemberian tempe dedak dan tape dedak terhadap meat bone ratio

\begin{tabular}{|c|c|c|c|c|c|}
\hline \multirow{2}{*}{ Perlakuan } & \multicolumn{4}{|c|}{ Ulangan } & \multirow{2}{*}{ Rata- Rata \pm SD } \\
\hline & U1 & U2 & U3 & U4 & \\
\hline PO & 5,55 & 4,79 & 7,13 & 5,23 & $5,67 \pm 1,02$ \\
\hline P1 & 5,93 & 5,08 & 7,00 & 6,66 & $6,17 \pm 0,58$ \\
\hline P2 & 5,63 & 5,71 & 7,19 & 7,77 & $6,58 \pm 1,07$ \\
\hline P3 & 5,15 & 5,63 & 7,22 & 3,82 & $5,46 \pm 1,41$ \\
\hline P4 & 5,24 & 6,39 & 5,21 & 5,93 & $5,70 \pm 0,57$ \\
\hline
\end{tabular}

Keterangan : $\mathrm{ns}=$ menunjukkan perlakuan berpengaruh tidak nyata $(\mathrm{P}>0,05) ; \mathrm{P0}=$ pakan mengandung 5\% dedak, $\mathrm{P} 1=$ pakan mengandung $14 \%$ tempe dedak, $\mathrm{P} 2=$ pakan mengandung $20 \%$ tempe dedak, $\mathrm{P} 3=$ pakan mengandung $14 \%$ tape dedak, $\mathrm{P} 4=$ pakan mengandung $20 \%$ tape dedak; SD= Standar Deviasi

\section{Cooking Loss}

Pengaruh pemberian tempe dedak dan tape dedak terhadap cooking loss disajikan pada Tabel 5. Hasil analisis ragam menunjukkan bahwa pemberian tempe dedak dan tape dedak berpengaruh tidak nyata $(P>0,05)$ terhadap cooking loss.

Meskipun berpengaruh tidak nyata P2 cenderung mempunyai cooking loss terendah. Selain itu, pemberian tempe dedak dan tape dedak pada level $14 \%$ memiliki nilai cooking loss yang cenderung lebih tinggi dibanding dengan tempe dedak dan tape dedak pada level $20 \%$. Soeparno (2015) menyatakan daging dengan cooking loss lebih rendah mempunyai kualitas relatif lebih baik daripada daging dengan cooking loss lebih besar, karena kehilangan nutrisi selama pemasakan akan lebih sedikit sehingga daging ayam dengan cooking loss rendah akan mempunyai kualitas yang lebih baik dibandingkan dengan daging ayam dengan susut masak tinggi. Berdasarkan data cooking loss tempe dedak dan tape dedak dapat diberikan sampai dengan $20 \%$.

\section{Drip Loss}

Pengaruh pemberian tempe dedak dan tape dedak terhadap drip loss disajikan pada Tabel 6 . Hasil analisis ragam menunjukkan bahwa pemberian tempe dedak dan tape dedak berpengaruh tidak nyata $(P>0,05)$ terhadap drip loss.

Meskpiun berpengaruh tidak nyata P2, P3 dan P4 mempunyai drip loss yang lebih rendah dari pada PO. Kecenderungan ini menguntungkan karena drip loss yang lebih rendah berarti kehilangan cairan yang lebih rendah selama penyimpanan. Rataan drip loss pada penelitian ini berkisar antara 10,96\% 13,83\%. Nurkhasanah (2015) melaporkan bahwa drip loss yang diberi ekstrak daun katuk pada broiler yang berumur 35 hari berkisar antara 5,22-5,72\%. Santoso (2014) menyatakan daya mengikat air pada daging dipengaruhi oleh protein daging, karena protein yang tinggi di daging maka kemampuan mengikat air akan 
meningkat sehingga cairan yang keluar selama pelayuan akan lebih sedikit. Berdasarkan data drip loss yang diperoleh, tempe dedak dan tape dedak dapat diberikan sebanyak $20 \%$. Berdasarkan hasil penelitian dapat disimpulkan bahwa tempe dedak dan tape dedak sdapat digunakan dalam ransum ayam broiler sebanyak 20\% tanpa menurunkan kualitas karkas.

Tabel 5. Pengaruh pemberian tempe dedak dan tape dedak terhadap cooking loss

\begin{tabular}{|c|c|c|c|c|c|}
\hline \multirow{2}{*}{ Perlakuan } & \multicolumn{4}{|c|}{ Ulangan } & \multirow{2}{*}{ Rata- Rata \pm SD } \\
\hline & U1 & U2 & U3 & U4 & \\
\hline \multicolumn{6}{|c|}{...\%, } \\
\hline PO & 43,98 & 41,78 & 41,08 & 40,14 & $41,74 \pm 1,63$ \\
\hline P1 & 36,53 & 59,52 & 42,78 & 33,73 & $43,14 \pm 11,55$ \\
\hline P2 & 41,21 & 37,93 & 35,78 & 33,97 & $37,22 \pm 3,11$ \\
\hline P3 & 30,70 & 33,86 & 42,75 & 54,31 & $40,40 \pm 10,58$ \\
\hline P4 & 41,61 & 36,73 & 42,70 & 35,76 & $39,20 \pm 3,46$ \\
\hline
\end{tabular}

Probabilitas

$0,815^{\text {ns }}$

ns $=$ menunjukkan perlakuan berpengaruh tidak nyata $(\mathrm{P}>0,05) ; \mathrm{P} 0=$ pakan mengandung $5 \%$ dedak, $\mathrm{P} 1=$ pakan mengandung $14 \%$ tempe dedak, $\mathrm{P} 2=$ pakan mengandung $20 \%$ tempe dedak, $\mathrm{P} 3=$ pakan mengandung 14\% tape dedak, $\mathrm{P} 4=$ pakan mengandung $20 \%$ tape dedak; $\mathrm{SD}=\mathrm{Standar}$ Deviasi

Tabel 6. Pengaruh pemberian tempe dedak dan tape dedak terhadap drip loss

\begin{tabular}{|c|c|c|c|c|c|}
\hline \multirow{2}{*}{ Perlakuan } & \multicolumn{4}{|c|}{ Ulangan (gram/ekor) } & \multirow{2}{*}{ Rata- Rata $\pm S D$} \\
\hline & U1 & U2 & U3 & U4 & \\
\hline & \multicolumn{5}{|c|}{ 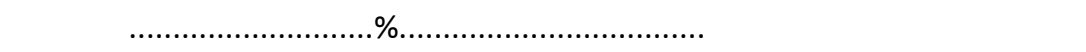 } \\
\hline PO & 12,71 & 16,82 & 9,96 & 13,64 & $13,28 \pm 2,83$ \\
\hline P1 & 14,07 & 13,98 & 15,69 & 11,62 & $13,83 \pm 1,67$ \\
\hline P2 & 11,07 & 11,88 & 10,75 & 10,15 & $10,96 \pm 0,72$ \\
\hline P3 & 13,32 & 7,78 & 11,46 & 12,50 & $11,27 \pm 2,44$ \\
\hline P4 & 14,08 & 9,83 & 8,51 & 15,18 & $11,90 \pm 3,23$ \\
\hline
\end{tabular}

Probabilitas

$0,376^{\text {ns }}$

$\mathrm{ns}=$ menunjukkan perlakuan berpengaruh tidak nyata $(\mathrm{P}>0,05) ; \mathrm{PO}=$ pakan mengandung $5 \%$ dedak, $\mathrm{P} 1=$ pakan mengandung $14 \%$ tempe dedak, $\mathrm{P} 2=$ pakan mengandung $20 \%$ tempe dedak, $\mathrm{P} 3=$ pakan mengandung 14\% tape dedak, P4= pakan mengandung 20\% tape dedak; SD= Standar Deviasi

\section{Kesimpulan}

Tempe dedak dan tape dedak masingmasing dapat diberikan kepada ayam broiler sebanyak $20 \%$ tanpa menurunkan kualitas karkas. Pemberian 20\% tape dedak menurunkan warna karkas.

\section{Daftar Pustaka}

Alfi, M. 2009. Pengaruh Penggunaan Tepung Roti Afkit Sebagai Pengganti Jagung dalam Ransum terhadap Produksi Karkas Ayam
Broiler Jantan. Universitas Diponegoro., Semarang.

Bidura, I.G.N.G. 2007. Aplikasi Produk Bioteknologi Pakan Ternak. Penerbit Udayana University Press. Denpasar.

Bidura, I. G. N. G, I. G. Mahardika, I. P. Suyadnya, I. B. G. Pratama, I. G. L. Oka, D. P. M. A. Candrawati, and I. G. A. I Aryani. 2012. The implementation of saccharomyces spp.n-2 isolated culture (isolation from traditional yeast culture) for improving feed quality and performance of male bali ducking. Agric. Sci. Res. J., 2 (9): 486-492. 
Campagne, E.T., R.J. Hron., and G Abraham. 1992. Stabilizing brown rice to lipolityc hydroliysis by ethanol vapors. Cereal Chemisthry. 69:152:156

Fatimah, S., U. Santoso, Y. Fenita dan Kususiyah. 2020. Pengaruh penggunaan tempe dedak dan tape dedak terhadap performa ayam broiler. Jurnal Sain Peternakan Indonesia, 15 (2): 124-131.

Fitriyani, S., U. Santoso dan T. Akbarillah. 2019. Pengaruh pemberian tempe dedak terhadap performa ayam broiler. Jurnal Sain Peternakan Indonesia, 14 (3): 246-251.

Kiers, J. L., J. C. Meijer, M. J. R. Nout, F. M. Rombouts, M. J. A. Nabuurs and J. Van Der Meulen. 2003. Effect of fermented soya beans on diarrhea and feed efficiency in weaned piglets. J. Appl. Microbiol., 95:545.

Kurniati, S., U. Santoso dan Y. Fenita. 2020. Pengaruh tempe dedak dan tape dedak terhadap karakteristik organoleptik daging broiler. Buletin Peternakan Tropis, 1 (2): $73-$ 79.

Mahfudz, L. D., K. Hayashi, M. Hamada, A. Ohtsuka, and Y. Tomita. 1996. The effective use of shochu ditellery by-product as growth promoting factor for broiler chicken. Japanese Poultry Sci., 33 (1): 1-7.

Nurkhasanah. B. 2015. Pengaruh suplementasi ekstrak daun katuk (Sauropus androgynus) dan tepung kunyit (Curcuma domestica) terhadap kualitas karkas ayam broiler yang diberi pakan berprotein rendah. Skripsi. Jurusan Peternakan, Fakultas Pertanian, Universitas Bengkulu. Bengkulu.
Samudera, R dan A. Hidayatullah. 2008. Warna kulit, lemak abdomen dan lemak karkas itik Alabio (Anas plathyrhincos Borneo) jantan akibat pemberian Azolla dalam ransum. Anim. Prod., 10 (3): 164-167.

Santoso, U. 2014. Katuk Tumbuhan Multi Khasiat. Badan Penerbit Fakultas Pertanian (BPFP) Universitas Bengkulu, Bengkulu.

Santoso, U., Y. Fenita, Kususiyah and Bidura, I. G. N. G. 2015. Effect of fermented Sauropus androgynous leaves on meat composition, amino acid and fatty acid composition in broiler chickens. Pak. J. Nutr., 14(11):799807.

Saunders, R.M. 1985. Rice bran: composition and potential food sources. Food Rev. Int., 1 (3):465-495.

Soeparno. 2015. Ilmu dan Teknologi Daging. Cetakan Keempat. Gadjah Mada University Press, Yogyakarta.

Vandrell, A.M. P., J. M. Hernandez., L. Llaurado., J. Schierle., J. Brufau. 2001. Influence of source and ratio of xantofilpigments on broiler chicken pigmentation and performance. J. Poultry Sci., 80. 320-326.

Widiastuti, U. 2017. Pengaruh pemberian tempe dedak terhadap karkas ayam broiler. Skripsi. Jurusan Peternakan Fakultas Pertanian Universitas Bengkulu. Bengkulu.

Widiyazid, S.I.K., I.A. Parwati., N. Suyasa., S. Guntoro., I.M. Londra., I.K. Triagastia., A.A.G Putra., dan G.M. Widianta. 2002. Laporan akhir pengkajian sistem usaha pertanian sapi potong berbasis ekoregional lahan kering. Instalasi Penelitian dan Pengkajian Teknologi Pertanian, Denpasar. 